\title{
NIELEGALNA MIGRACJA W EUROPIE - ASPEKTY PRAWNE I KRYMINOLOGICZNE
}

\author{
Magdalena Perkowska \\ Uniwersytet w Białymstoku \\ Wydział Prawa, Zakład Prawa Karnego i Kryminologii \\ e-mail: magdalena.perkowska@gmail.com
}

\begin{abstract}
Streszczenie. W dobie aktualnej dyskusji nad problemem nielegalnej migracji w Europie warto pochylić się nad analizą zachowań stanowiących ten proceder. Stąd też pierwsza część artykułu została poświęcona wskazaniu zachowań, które ogólnie nazywane są nielegalną migracją. Są to przekroczenie granicy wbrew przepisom, posługiwanie się fałszywym dokumentem czy nielegalny pobyt. Podjęto prawną analizę tych zachowań celem wskazania, czy stanowią one naruszenie prawa - szczególnie prawa polskiego. W drugiej części artykułu przybliżono fenomen zjawiska ukazując jego dynamikę w ostatnich pięciu latach, jak również jego strukturę w odniesieniu do form wskazanych w części pierwszej.
\end{abstract}

Słowa kluczowe: migracja, przekroczenie granicy wbrew przepisom, uchodźcy

\section{WSTĘP}

W dobie aktualnej dyskusji nad problemem nielegalnej migracji do Europy warto przyjrzeć się jakie formy przybiera ten proceder. Zatem celem niniejszego opracowania jest próba udzielenia odpowiedzi na pytanie czy nielegalna migracja jest procederem, który nie jest zgodny z prawem. Ponadto należy zastanowić się czy i w jakich okolicznościach możliwe jest pociągnięcie imigrantów do odpowiedzialności karnej lub administracyjnej za naruszenie zasad wjazdu na terytorium państwa czy zasad legalnego pobytu.

W badaniach przeprowadzonych na potrzeby artykułu posłużono się głównie metodą statystyczną. Statystyki urzędowe, w tym kryminalne dostarczają danych pozwalających ustalać dynamikę ujawnionych zjawisk. ${ }^{1}$ Metoda ta pozwoliła na uzyskanie szeregu istotnych informacji nt. rozmiarów i dynamiki nielegalnego

\footnotetext{
1 W. Świda, Kryminologia, PWN Warszawa 1977, s. 25.
} 
przekroczenia granicy w UE. Analizy statystyczne oparto przede wszystkim na danych Europejskiej Agencji Zarządzania Współpracą Operacyjną na Zewnętrznych Granicach Państw Członkowskich Unii Europejskiej (Frontex). Ponadto wykorzystano metodę analizy literatury w tym także raportów wskazanej instytucji.

Unia Europejska, zgodnie z celem wskazanym w art. 3 Traktatu o UE², zapewnia swoim obywatelom przestrzeń wolności, bezpieczeństwa i sprawiedliwości bez granic wewnętrznych, w której zagwarantowana jest swoboda przepływu osób, w powiązaniu z właściwymi środkami w odniesieniu do kontroli granic zewnętrznych, azylu, imigracji, jak również zapobiegania i zwalczania przestępczości.

Już w art. 3 TUE podkreślone zostało znaczenie bezpieczeństwa granic zewnętrznych oraz istotny aspekt zapobiegania i zwalczania przestępczości, a ponadto w rozdziale 2 Traktatu o funkcjonowania Unii Europejskiej ${ }^{3}$ poświęconym polityce dotyczącej kontroli granicznej, azylu i imigracji szczególnie zwrócono uwagę na zapewnienie kontroli i skutecznego nadzoru przy przekraczaniu granic zewnętrznych. Za jeden z ważnych elementów tej polityki uznano zapobieganie nielegalnej migracji i handlowi ludźmi.

Aktualnie nielegalna migracja stanowi ogromny problem w Europie. Z kryminologicznej perspektywy warto przyjrzeć się temu jakie czyny, jakie zachowania stanowią nielegalną migrację, i czy w każdym przypadku możemy mówić właśnie o procederze, który nie jest zgodny z prawem.

\section{FORMY NIELEGALNEJ MIGRACJI - ASPEKTY PRAWNE}

Analizując sytuację na granicach zewnętrznych UE pod względem przemieszczania się osób Agencja Frontex, poza wskazaniem liczby osób przekraczających granice oraz liczby wydanych wiz, podaje dane według określonych wskaźników. Do tych wskaźników zaliczono liczby osób, które:

1) nielegalnie przekroczyły granicę poza przejściami granicznymi,

2) przekroczyły granicę przez przejście graniczne w ukryciu,

3) posługiwały się fałszywym dokumentem przy przekroczeniu granicy,

4) otrzymały decyzję o odmowie wjazdu,

5) przebywały nielegalnie na terytorium państwa członkowskiego UE,

6) otrzymały decyzję o zobowiązaniu do powrotu,

7) wobec których wykonano decyzję o zobowiązaniu do powrotu,

8) swoim zachowaniem ułatwiały nielegalne przekroczenie granicy.

2 Traktat o Unii Europejskiej 13.12.2007, Dz. Urz. UE 2012 C, 326/13.

3 Traktat o funkcjonowaniu Unii Europejskiej, Wersja skonsolidowana Traktatu o funkcjonowaniu Unii Europejskiej Dz. Urz. UE 2008 C 115/47. 
Tabela 1. Obraz statystyczny zjawiska nielegalnej migracji w Unii Europejskiej

\begin{tabular}{|l|r|r|r|r|r|}
\hline \multicolumn{1}{|c|}{ Forma } & \multicolumn{1}{|c|}{2011} & \multicolumn{1}{|c|}{2012} & \multicolumn{1}{c|}{2013} & \multicolumn{1}{c|}{2014} & \multicolumn{1}{c|}{2015} \\
\hline $\begin{array}{l}\text { Nielegalne przekroczenia } \\
\text { granicy poza przejściami } \\
\text { granicznymi }\end{array}$ & 141051 & 72437 & 107365 & 283532 & 1822337 \\
\hline Przemyt migrantów & 282 & 591 & 599 & 3052 & 3642 \\
\hline $\begin{array}{l}\text { Posługiwanie się fałszywym } \\
\text { dokumentem }\end{array}$ & 5255 & 7804 & 9804 & 9420 & 8373 \\
\hline Odmowa wjazdu & 118277 & 116524 & 129235 & 114887 & 118495 \\
\hline Nielegalny pobyt & 350948 & 344928 & 345098 & 441780 & 701625 \\
\hline $\begin{array}{l}\text { Wydane decyzje zobowiązaniu } \\
\text { do powrotu }\end{array}$ & 231385 & 269949 & 224305 & 252003 & 286725 \\
\hline $\begin{array}{l}\text { Wykonane decyzje } \\
\text { zobowiązaniu do powrotu }\end{array}$ & 149045 & 158955 & 160418 & 161309 & 175220 \\
\hline
\end{tabular}

Źródło: Frontex, Annual Risk Analysis 2015, s. 12; Annual Risk Analysis 2016, s. 14.

Przekroczenie granicy poza przejściami granicznymi jest wyłącznie dozwolone na odcinkach granicy wewnętrznej UE i strefy Schengen zgodnie z art. 20 kodeksu granicznego Schengen. ${ }^{4}$ Wskazano w nim, iż przekraczanie granicy wewnętrznej możliwe jest w każdym miejscu bez dokonywania odprawy granicznej osób niezależnie od ich obywatelstwa. Natomiast przekraczanie odcinków granicy zewnętrznej możliwe jest jedynie na przejściach granicznych (art. 4 kodeksu granicznego Schengen).

W prawie międzynarodowym według Konwencji o prawach i obowiązkach państw przyjętej na VII konferencji panamerykańskiej w Montevideo, państwo, jako osoba prawa międzynarodowego powinno posiadać następujące atrybuty: a) stałą ludność, b) określone terytorium, c) rząd, d) zdolność do utrzymywania stosunków z innymi państwami. ${ }^{5}$ Terytorium państwa, które zgodnie z prawem międzynarodowym jest przestrzenią na jakiej obowiązuje władza suwerenna określonego państwa, umożliwia utrzymanie stosunków z innymi państwami. Terytorium państwowe jest wyznaczone granicami państwowymi, które jednocześnie określają zasięg suwerenności władzy danego państwa. Z suwerenności państwa wynika uprawnienie do decydowania kto i na jakich warunkach może wjechać na jego terytorium. Ochrona granicy państwowej należy do wyłącznych kompetencji państwa.

Z punktu widzenia prawodawstwa europejskiego nie ma aktu prawnego zobowiązującego państwa członkowskie do penalizacji nielegalnego przekroczenia granicy, jednak większość państw UE uznaje to zachowanie za zabronione. Jako

4 Rozporządzenie(WE) nr 562/2006 Parlamentu Europejskiego i Rady z dnia 15 marca 2006 r. ustanawiającego wspólnotowy kodeks zasad regulujących przepływ osób przez granice (kodeks graniczny Schengen) Dz. Urz. UE L 105 z 13.04.2006, str. 1, ze zm.

5 W. Góralczyk, S. Sawicki, Prawo międzynarodowe publiczne w zarysie, Lexis-Nexis, Warszawa 2013, s. 119. 
wyjątek można wskazać Hiszpanię gdzie nielegalne przekroczeniem granicy nie jest przestępstwem, a imigrant ma prawo do pozostawania na jej terytorium, jeśli po 40 dniach od jego ujęcia władze nie rozpoczną procedury wydalenia. ${ }^{6}$ Zgodnie z prawem polskim przekroczenie granicy Rzeczypospolitej Polskiej wbrew przepisom może stanowić wykroczenie lub przestępstwo w postaci występku. ${ }^{7}$

Zgodnie $\mathrm{z}$ art. 49a kw ${ }^{8}$ wykroczeniem jest przekroczenie granicy Rzeczypospolitej Polskiej wbrew przepisom, a zatem nie jest karalne przekroczenie granicy innego państwa. Zasady legalnego przekroczenia granicy określa szereg aktów prawny tj. Ustawa o cudzoziemcach ${ }^{9}$ oraz Ustawa o ochronie granicy państwowej ${ }^{10}$.

Momentem przekroczenia granicy państwowej jest moment, gdy funkcjonariusz Straży Granicznej ukończył już czynności polegające na sprawdzeniu ważności i autentyczności dokumentów uprawniających do przekroczenia polskiej granicy państwowej przy równoczesnym ustaleniu tożsamości sposoby legitymującej się tymi dokumentami ${ }^{11}$ a sprawca znalazł się po zewnętrznej lub wewnętrznej stronie granicy. $Z$ nielegalnym przekroczeniem granicy możemy mieć do czynienia zarówno, gdy sprawca przekroczył ją w miejscu niedozwolonym (tzw. zielona granica), jak i w dozwolonym, lecz wbrew przepisom o jej przekraczaniu. $^{12}$

Zachowanie sprawcy polega na każdym pokonaniu granicy RP np. bez posiadania i okazania wymaganego dokumentu lub też w miejscu, które zostało wyznaczone jako przejście graniczne, bez względu na środek lokomocji lub też

${ }^{6} \mathrm{O}$. Łachacz, Zwalczanie nielegalnej imigracji w Unii Europejskiej $w$ aspekcie wspólnej polityki imigracyjnej i polityki wybranych państw członkowskich w tym zakresie, [w:] T. Jasudowicz, M. Balcerzak (red.) Ksiega pamiatkowa ku czci Profesora Jana Białocerkiewicza T. 1, TNOiK Toruń 2009, s. 524.

${ }^{7}$ M. Perkowska, Prawne i kryminologiczne aspekty dekryminalizacji przestępstwa nielegalnego przekroczenia granicy, [w:] S. Pikulski, M. Romańczuk-Grącka (red.), Granice kryminalizacji i penalizacji, Pracownia Wydawnicza „Elset” Olsztyn 2013, s. 505-515.

${ }^{8}$ Ustawa z dnia z dnia 20 maja 1971 r. Kodeks wykroczeń, Dz. U. nr 12 poz. 114 ze zm.

${ }^{9}$ Ustawa z dnia 12 grudnia 2013 r. o cudzoziemcach, Dz. U. poz. 1650 ze zm. Ustawa o cudzoziemcach wskazuje w art. 23, iż cudzoziemiec, który przekracza granicę, jest obowiązany posiadać: 1) ważny dokument podróży; 2) ważną wizę lub inny ważny dokument uprawniający go do wjazdu na terytorium Rzeczypospolitej Polskiej i do pobytu na tym terytorium, jeżeli są wymagane; 3) zezwolenie na wjazd do innego państwa lub zezwolenie na pobyt w innym państwie, jeżeli zezwolenia takie są wymagane w przypadku przejazdu tranzytem. Ponadto ustawa w art. 24 wskazuje, iż cudzoziemiec zobowiązany jest uzasadnić cel i warunki planowanego pobytu; posiadać oraz okazać na żądanie: dokument potwierdzający posiadanie ubezpieczenia zdrowotnego oraz środki finansowe wystarczające na pokrycie kosztów planowanego pobytu oraz podróży powrotnej do państwa pochodzenia lub zamieszkania lub kosztów tranzytu do państwa trzeciego, które udzieli pozwolenia na wjazd, albo dokument potwierdzający możliwość uzyskania takich środków zgodnie z prawem.

${ }^{10}$ Ustawa z dnia 12 października 1990 r. o ochronie granicy państwowej, t.j. Dz. U. z 2015 r. poz. $930,1336$.

${ }^{11}$ Wyrok SN z 26.7.2001 r. V KKN 81/99, LEX nr 51670.

${ }^{12}$ W. Bojarski [w:] Kodeks wykroczeń. Komentarz, W. Bojarski, W. Radecki (red.), C.H. Beck Warszawa 2013, s. 396. 
bez niego. ${ }^{13}$ Zachowanie takie zagrożone jest karą grzywny do 5000 zł. zgodnie $\mathrm{z}$ art. $49 \mathrm{a} \mathrm{kw}$.

Jeżeli sprawca swoim zachowaniem odwołuje się do przemocy, groźby, podstępu lub współdziała z innymi osobami wypełnia znamiona występku określonego w art. $264 \S 2 \mathrm{kk}^{14}$, zagrożonego karą pozbawienia wolności do lat 3 .

Użycie ogólnego określenia przemoc oznacza, że chodzi zarówno o przemoc stosowaną wobec osoby (np. funkcjonariusza Straży Granicznej), jak i wobec rzeczy (np. staranowanie barier pojazdem mechanicznym i przekroczenie w ten sposób granicy). Również określenie groźba jest ogólne, obejmując groźbę użycia przemocy i groźbę bezprawną określoną w art. $115 \S 12 \mathrm{kk}$. Przez podstęp należy natomiast rozumieć inne działanie niż przemoc lub groźba, które wprowadza w błąd, umożliwiając nielegalne przekroczenie granicy (np. fałszywy alarm, odwołanie funkcjonariusza Straży Granicznej pod jakimś pozorem). ${ }^{15}$

W rzeczywistości zachowanie polegające na użyciu przemocy czy groźby przez sprawcę przekroczenia granicy wbrew przepisom występuje dość rzadko. Częściej w praktyce funkcjonariusze Straży Granicznej mają do czynienia z użyciem podstępu czy zachowaniem polegającym na przekroczenia granicy we współdziałaniu z innymi osobami. Oznaczać to może zarówno, iż samo przekroczenie granicy nastąpiło „wspólnie z innymi osobami, które ze sobą współdziałały", jak i to, że doprowadzenie do nielegalnego przekroczenia granicy przez samego sprawcę było możliwe dzięki współdziałaniu innych osób. Możliwy jest, jak twierdzi Z. Ćwiąkalski, układ mieszany, polegający na tym, że kilka osób nielegalnie przekroczyło we współdziałaniu granicę, przy czym możliwe stało się to ze względu na współdziałanie z innymi osobami. ${ }^{16}$ Sprawca lub sprawcy muszą współdziałać z co najmniej dwiema dalszymi osobami, skoro Ustawa wymaga współdziałania $\mathrm{z}$,innymi” osobami. Tymi współdziałającymi mogą być dowolne osoby postronne, mogące ułatwić nielegalne przekroczenie granicy. Współdziałanie zaistnieje wtedy gdy kilka osób wspólnie nielegalnie przekroczy granicę jak i wtedy gdy przekroczenia granicy dokona jedna osoba, której pomagają inne osoby. ${ }^{17}$

Zachowanie polegające na przemycie/przerzucie migrantów (ang. clandestine entry lub smuggling of persons) polega na przewiezieniu cudzoziemca przez granicę w ukryciu, podobnie jak przemycane są towary, stąd też autorka posługuje się terminem przemytu migrantów. W tym celu najczęściej wykorzystywane są części ładunkowe i skrytki pojazdów ciężarowych, ale także bagażniki samochodów osobowych, a nawet deski rozdzielcze. Cudzoziemiec przekraczający w ten

\section{${ }^{13}$ Ibidem.}

${ }^{14}$ Ustawa z dnia 6 czerwca 1997 r. Kodeks karny, Dz. U. Nr 88, poz. 553.

${ }^{15}$ A. Marek, Kodeks karny. Komentarz, Dom Wydawnicy ABC Warszawa 2004, s. 547

${ }^{16}$ Z. Ćwiąkalski [w:], Kodeks karny. Część szczególna. Tom II. Komentarz do art. 117-277 k.k., Wolters Kluwer Warszawa 2008, s. 1238.

${ }^{17}$ M. Jachimowicz, Nowe zasady odpowiedzialności za nielegalne przekroczenie granicy RP, „Prokuratura i Prawo” 2006, nr 5, s. 59. 
sposób granicę odpowie na podstawie art. 49a kw lub 264 § kk. Sprawca, który organizuje takie przekroczenie granicy zgodnie z prawem polskim odpowie na podstawie art. $264 \S 3 \mathrm{kk}$ przewidującego karalność organizowania innym osobom przekraczania granicy RP wbrew przepisom.

W tym miejscu należy zwrócić uwagę na regulacje UE w zakresie karania ułatwiania nielegalnego przekraczania granicy oraz nielegalnego pobytu. Jak wspomniano powyżej prawodawstwo UE nie zobowiązującego państwa członkowskie do penalizacji nielegalnego przekroczenia granicy, ale powzięto inne inicjatywy mające na celu przeciwdziałanie nielegalnej migracji. W dyrektywie Rady 2002/90/ $\mathrm{WE}^{18}$ zawarto definicję ułatwiania nielegalnego wjazdu, tranzytu i pobytu. Postanowienia tej dyrektywy wzmocniła decyzja ramowa w sprawie wzmocnienia systemu karnego w celu zapobiegania ułatwianiu nielegalnego wjazdu, tranzytu i pobytu. ${ }^{19}$ Unia Europejska regulując kwestie związane z nielegalną imigracją w dyrektywie Parlamentu Europejskiego i Rady 2009/52/WE ${ }^{20}$ przewidziała minimalne normy w odniesieniu do kar i środków stosowanych wobec pracodawców zatrudniających nielegalnie przebywających obywateli krajów trzecich. ${ }^{21}$

W aktualnej sytuacji, z jaką mierzy się Europa w związku z napływem migrantów z Afryki i Bliskiego Wschodu pojawiają się pytania o zgodność z prawem przekroczenia granicy zewnętrznej UE/Schengen, szczególnie tych osób, które składają wnioski o nadanie statusu uchodźcy czy innej ochrony międzynarodowej.

Art. 31 ust 1 Konwencji Genewskiej dotyczącej statusu uchodźcy ${ }^{22}$ stanowi, iż nie podlega karze tylko ten cudzoziemiec, który przekroczył nielegalnie granicę z powodów określonych w art. 31 ust. 1 konwencji genewskiej. W związku z tym organy ścigania muszą ustalić, czy zatrzymany jest:

- uchodźcą w rozumieniu art. 1 Konwencji Genewskiej ${ }^{23}$,

${ }^{18}$ Dyrektywa Rady 2002/90/WE z dn. 28 listopada 2002 r. definiująca ułatwianie nielegalnego wjazdu, tranzytu i pobytu, Dz. U. UE. L. z 2002 r., Nr 328, poz. 17.

${ }^{19}$ Decyzja Ramowa Rady 2002/946/WSiSW z dn. 28 listopada 2002 r. w sprawie wzmocnienia systemu karnego w celu zapobiegania ułatwianiu nielegalnego wjazdu, tranzytu i pobyt, Dz. U. UE. L. z 2002 r., Nr 328, poz. 1.

${ }^{20}$ Dyrektywa Parlamentu Europejskiego i Rady 2009/52/WE/WE z dn. 18 czerwca 2009 r. przewidująca minimalne normy w odniesieniu do kar i środków stosowanych wobec pracodawców zatrudniających nielegalnie przebywających obywateli krajów trzecich, Dz. U. UW L. z 2009 r., Nr 168, poz. 24 .

${ }^{21}$ M. Perkowska, E. Jurgielewicz, Zwalczanie nielegalnej migracji w polskim prawie karnym - wybrane aspekty implementacji prawa Unii Europejskiej, „Białostockie Studia Prawnicze” 2014, nr 15, s. 71-82.

${ }^{22}$ Konwencja dotycząca statusu uchodźców, sporządzona w Genewie dnia 28 lipca 1951 r., Dz. U. 1991 nr 119 poz. 515.

${ }^{23}$ Art. 1 konwencji genewskiej stanowi iż uchodźcą jest osoba, która na skutek uzasadnionej obawy przed prześladowaniem z powodu swojej rasy, religii, narodowości, przynależności do określonej grupy społecznej lub z powodu przekonań politycznych przebywa poza granicami państwa, którego jest obywatelem, i nie może lub nie chce z powodu tych obaw korzystać z ochrony tego państwa, albo która nie ma żadnego obywatelstwa i znajdując się na skutek podobnych zdarzeń, 
- przybywającym bezpośrednio z terytorium, na którym jego życiu lub wolności zagraża niebezpieczeństwo,

- bezzwłocznie zgłosił się do władz i przedstawia wiarygodne przyczyny swojego nielegalnego wjazdu lub pobytu.

Uzasadnione przypuszczenie, że takie okoliczności występują, będzie oznaczać niedopuszczalność pociągnięcia cudzoziemca do odpowiedzialności karnej za popełnienie przestępstwa czy też wykroczenia polegającego na nielegalnym przekroczeniu granicy.

Ani polskie prawo karne, ani prawo wykroczeń nie posiada expresis verbis przepisów znoszących odpowiedzialności karną osób nielegalnie przekraczających granice, których celem jest ubieganie się o nadanie statusu uchodźcy. Nie oznacza to jednak, że osoby takie podlegają odpowiedzialności karnej zgodnie z polskim prawem. Odpowiedzialność może zostać uchylona m.in. poprzez bezpośrednie zastosowanie przepisów art. 31 ust. 1 Konwencji Genewskiej.

W aktualnej sytuacji dużego napływu imigrantów szczególnie z Syrii do Europy należy wskazać, iż migranci ci mogą ubiegać się o nadanie statusu uchodźcy pod warunkiem, iż jak wskazuje art. 31 Konwencji, przybędą na terytorium Europy bezpośrednio z terytorium, na którym ich życiu lub wolności zagraża im niebezpieczeństwo. Z taką sytuacją nie mamy do czynienia gdy obywatele Syrii przybywają np. do Grecji z Turcji. W tych okolicznościach istnieje możliwość pociągnięcia do odpowiedzialności za przekroczenie granicy wbrew przepisom.

Analizując problem ubiegania się o udzielenie ochrony międzynarodowej należy przypomnieć, iż zgodnie z art. 13 Rozporządzenia Dublin III $^{24}$ w sytuacji, kiedy cudzoziemiec przekroczył nielegalnie granicę lądową, morską lub powietrzną państwa członkowskiego, przybywając z państwa trzeciego, państwo członkowskie, do którego w ten sposób wjechał, jest odpowiedzialne za rozpatrzenie wniosku (odpowiedzialność ta wygasa z upływem dwunastu miesięcy od dnia, kiedy nastąpiło nielegalne przekroczenie granicy). Jeśli cudzoziemiec znajdzie się na terytorium innego państwa członkowskiego zostanie przekazany do państwa odpowiedzialnego za rozpatrzenie wniosku.

Kolejną formą sprzecznego z prawem przedostania się na terytorium państwa członkowskiego jest jak wskazuje Frontex posłużenie się fałszywym dokumentem. Cudzoziemcy posługują się podrobionymi lub przerobionymi dokumentami. Największą liczbę fałszywych dokumentów stanowią paszporty. Obywatele państw trzecich posługują się także sfałszowanymi wizami, zezwoleniami na pobyt, innymi dokumentami tożsamości oraz podrabiają lub przerabiają odciski

poza państwem swojego dawnego stałego zamieszkania nie może lub nie chce z powodu tych obaw powrócić do tego państwa.

${ }^{24}$ Rozporządzenie Parlamentu Europejskiego i Rady (UE) Nr 604/2013 z dnia 26 czerwca 2013 r. w sprawie ustanowienia kryteriów i mechanizmów ustalania państwa członkowskiego odpowiedzialnego za rozpatrzenie wniosku o udzielenie ochrony międzynarodowej złożonego w jednym z państw członkowskich przez obywatela państwa trzeciego lub bezpaństwowca (wersja przekształcona), Dziennik Urzędowy L 050, 25/02/2003. 
stempli, głównie potwierdzające odprawę graniczną. Posługiwanie się podrobionym, lub przerobionym dokumentem stanowi w prawie polskim, ale także w prawie pozostałych państw UE czyn zabroniony.

Zgodnie z art. $270 \mathrm{kk}$ przestępstwo materialnego fałszerstwa dokumentu (art. 270 § 1 in principio) może być popełnione albo przez podrobienie, albo przez przerobienie dokumentu. Istota podrobienia dokumentu polega na sporządzeniu takiego zapisu informacji, któremu nadaje się pozory autentyczności, w szczególności zaś, iż pochodzi od określonego wystawcy. Dla realizacji znamion podrobienia dokumentu wystarczające jest podrobienie tylko jego fragmentu (np. podpisu wystawcy, czy też pieczęci lub daty, o ile ma ona znaczenie prawne). Uczynienie dopisków czy wprowadzenie nowych elementów do istniejącego już dokumentu nie jest jego podrobieniem, lecz przerobieniem. ${ }^{25}$ Natomiast przerobienie dokumentu polega na nadaniu mu innej treści niż pierwotnie posiadał. Przerobienie polegać może na dokonaniu skreśleń, wymazaniu, uczynieniu dopisków, wywabieniu. Dla realizacji znamion podrobienia lub przerobienia dokumentu nie ma znaczenia, czy jego treść odpowiada stwierdzonym w nich stanom faktycznym, czy też nie. ${ }^{26}$

Niezależnie od karalności fałszu materialnego art. 270 kk przewiduje odpowiedzialność karną za używanie jako autentycznego dokumentu podrobionego lub przerobionego. Pojęcie używania sprowadza się do wykorzystywania funkcji, jakie może pełnić podrobiony lub przerobiony dokument. ${ }^{27}$ Użyciem dokumentu będzie przedstawienie go osobie uprawnionej do kontroli, czy zrealizowanie na jego podstawie określonego świadczenia, wprowadzenie do rejestru, dokonanie na jego podstawie określonej operacji księgowej, przedłożenie organowi prowadzącemu określone postępowanie dowodowe. ${ }^{28}$

Cudzoziemcy posługują się także metodą na podobieństwo tzw. look alike. Polega ona na posługiwaniu się dokumentami innych osób (oryginalnymi lub podrobionymi), które są przesyłane pocztą lub poprzez kuriera pomiędzy państwami. Polska Straż Graniczna ujawniła taki proceder np. w przypadku obywateli Nigerii i Chin a także Ukrainy, którzy jak się okazuje podczas kontroli, posiadają przy sobie także dokumenty innej osoby (paszporty, prawa jazdy, karty pobytu). Ujawnione przesyłki pocztowe zawierają paszporty np. nigeryjskie ze zmienionymi danymi osobowymi i innymi fotografiami. Na pozostałych odcinkach granicy zewnętrznej ujawniane są podobne przypadki działania obywateli Syrii, Albanii, Ukrainy, Iranu czy Chin. ${ }^{29}$

Kolejną formą nielegalnej migracji jest nielegalny pobyt. Przyczyną nielegalnego pobytu może być zarówno nielegalny wjazd poprzez nielegalne prze-

${ }^{25}$ W. Wróbel [w:], Kodeks karny. Czesść szczególna. Komentarz do art. 117-277 Tom II, A Zoll (red.), Wolters Kluwer Warszawa 2008, s. 1538-1340.

${ }^{26}$ Ibidem.

${ }^{27}$ A. Herzog, [w:] W: Kodeks karny. Komentarz, R.A. Stefański (red.), C.H. Beck Warszawa 2014, s. 1681 .

${ }^{28}$ W. Wróbel [w:], Kodeks karny, op. cit.

${ }^{29}$ Fontex, Annual Risk Analysis 2016, Warsaw 2016, s. 17, 21. 
kroczenie granicy - przejście przez zieloną granicę, posłużenie się fałszywym dokumentem. Jak również sytuacja, w której cudzoziemiec legalnie przekroczył granicę ale przedłużył swój pobyt poza okres ważności wizy lub innego zezwolenia. Nielegalny pobyt dotyczy również sytuacji, w których pozwolenie pobytowe cudzoziemca zostało cofnięte przez właściwy organ. ${ }^{30}$ Formą nielegalnego pobytu może być również zawarcie pozornego małżeństwa, którego wyłącznym celem jest legalizacja pobytu cudzoziemca. ${ }^{31}$

Nielegalny pobyt nie stanowi przestępstwa. Brak jest możliwości pociągnięcia sprawcy do odpowiedzialności karnej za pozostawanie na terytorium państwa bez tytułu prawnego, jeśli organy ścigania nie mają dowodów na popełnieni innego przestępstwa np. nielegalnego przekroczenia granicy, posługiwania się fałszywymi dokumentami czy w niektórych porządkach prawnych zawarcia pozornego małżeństwa lub pozorne przysposobienie dziecka. ${ }^{32}$

Zawarcie pozornego małżeństwa lub pozorne przysposobienie dziecka w prawie polskim może zostać uznane za umożliwienie lub ułatwienie innej osobie pobyt na terytorium RP a jest to przestępstwo zagrożone karą pozbawianie wolności od 3 miesięcy do 5 lat na podstawie art. 264a kk.

Nielegalny pobyt jest jednak podstawą do wydania decyzji o zobowiązaniu cudzoziemca do powrotu. Ramy takiej decyzji na gruncie UE wyznacza dyrektywa 2008/115/WE, która określa wspólne normy i procedury, które mają być stosowane przez państwa członkowskie w odniesieniu do powrotów nielegalnie przebywających obywateli państw trzecich. ${ }^{33}$ Zobowiązania do powrotu realizowane są dobrowolnie, w wyznaczonym przez organy terminie. W przypadku gdy obowiązanie do powrotu nie zostanie wykonane w terminie dobrowolnego wyjazdu następuje przymusowa realizacji zobowiązania w postaci wydalenia.

${ }^{30} \mathrm{Z}$ taką sytuacją mamy do czynienia gdy: 1) doszło do cofnięcia zezwolenia na zamieszkanie na pobyt czasowy (zgodnie z art. 101 ustawy o cudzoziemcach), stały (z art. 199 ustawy o cudzoziemcach) lub pobyt rezydenta długoterminowego UE (art. 215 ustawy o cudzoziemcach), 2) cudzoziemca pozbawiono statusu uchodźcy lub ochrony międzynarodowej w związku z przyczynami wskazanymi w art. 21 i 22 ustawy o udzielaniu cudzoziemcom ochrony na terytorium Rzeczypospolitej Polskiej.

${ }^{31} \mathrm{~W}$ prawie polskim postępowanie w tym zakresie prowadzone jest na podstawie art. 169 ustawy o cudzoziemcach) a jeśli przed upływem 2 lat od otrzymania zezwolenia na pobyt stały nastąpił rozwód postępowanie toczy się na podstawie art. 199 ust. 3 ustawy o cudzoziemcach (możliwość cofnięcia zezwolenia).

${ }^{32}$ Zgodnie z art. L. 623-1 francuskiego kodeksu wjazdu i pobytu cudzoziemców oraz prawa do azylu przestępstwem jest zawarcie związku małżeńskiego lub uznanie dziecka, którego wyłącznym celem jest otrzymanie zezwolenia na pobyt lub uniknięcie wydalenia albo uzyskanie obywatelstwa francuskiego. Odpowiedzialności karnej podlega także cudzoziemiec podejmujący wskazane czynności, bez ujawnienia ich celu drugiej stronie. Karze podlega także organizowanie lub usiłowanie organizowania fikcyjnych małżeństw lub adopcji. Czyny te zagrożone są karą pozbawienia wolności do pięciu lat oraz karą grzywny do 15000 Euro.

${ }^{33}$ Dyrektywa Parlamentu Europejskiego i Rady 2008/115/WE z dnia 16 grudnia 2008 r. w sprawie wspólnych norm i procedur stosowanych przez państwa członkowskie w odniesieniu do powrotów nielegalnie przebywających obywateli państw trzecich, Dz. Urz. UE L 348/98. 
W polskim prawie przesłanki wydania decyzji zobowiązującej do powrotu wskazuje Ustawa o cudzoziemcach ${ }^{34} \mathrm{w}$ art. 302 . W zakresie w jakim dotyczą one nielegalnego pobytu należy wskazać sytuacje, gdy cudzoziemiec :

1) przebywa lub przebywał na terytorium Rzeczypospolitej Polskiej bez ważnej wizy lub innego ważnego dokumentu uprawniającego go do wjazdu na to terytorium i pobytu na nim, jeżeli wiza lub inny dokument są lub były wymagane, lub

2) nie opuścił terytorium Rzeczypospolitej Polskiej po wykorzystaniu dopuszczalnego okresu jego pobytu na terytorium wszystkich lub niektórych państw obszaru Schengen, do którego był uprawniony bez konieczności posiadania wizy, w każdym okresie 180 dni, chyba że umowy międzynarodowe stanowią inaczej, lub

3) nie opuścił terytorium Rzeczypospolitej Polskiej po wykorzystaniu dopuszczalnego okresu jego pobytu wskazanego w wizie Schengen w każdym okresie 180 dni, lub po wykorzystaniu dopuszczalnego okresu pobytu na podstawie wizy krajowej, lub

4) przekroczył lub usiłował przekroczyć granicę wbrew przepisom prawa, lub

5) przebywa poza strefą przygraniczną, w której zgodnie z zezwoleniem na przekraczanie granicy w ramach małego ruchu granicznego może przebywać, chyba że umowy międzynarodowe stanowią inaczej, lub

6) przebywa na terytorium Rzeczypospolitej Polskiej po upływie okresu pobytu, do którego był uprawniony na podstawie zezwolenia na przekraczanie granicy w ramach małego ruchu granicznego, chyba że umowy międzynarodowe stanowią inaczej, lub

7) cel i warunki pobytu cudzoziemca na terytorium Rzeczypospolitej Polskiej są niezgodne z deklarowanymi, chyba że przepisy prawa dopuszczają ich zmianę, lub

8) została wydana decyzja o odmowie nadania statusu uchodźcy lub udzielenia ochrony uzupełniającej, o uznaniu wniosku o udzielenie ochrony międzynarodowej za niedopuszczalny, o umorzeniu postępowania w sprawie udzielenia ochrony międzynarodowej lub decyzja o pozbawieniu go statusu uchodźcy lub ochrony uzupełniającej i cudzoziemiec: nie opuścił terytorium Rzeczypospolitej Polskiej w wyznaczonym terminie albo przebywa w strzeżonym ośrodku albo w areszcie dla cudzoziemców.

Pozostałe przesłanki, które mogą skutkować wydaniem decyzji o zobowiązaniu do powrotu związane są z podejmowaniem nielegalnego zatrudnienia lub nielegalnego prowadzenia działalności gospodarczej. A także braku środków finansowych niezbędnych do pokrycia kosztów pobytu na terytorium Rzeczypospolitej Polskiej, podróży powrotnej, czy sytuacji, w której obowiązuje wpis danych cudzoziemca do wykazu cudzoziemców, których pobyt na terytorium RP jest niepożądany, lub dane cudzoziemca znajdują się w Systemie Informacyjnym

\footnotetext{
${ }^{34}$ Ustawa z dnia 12 grudnia 2013 r. o cudzoziemcach Dz. U. 2013 poz. 1650 ze zm.
} 
Schengen do celów odmowy wjazdu. Przyczyną wydania decyzji mogą być także względy obronności lub bezpieczeństwa państwa lub ochrony bezpieczeństwa i porządku publicznego lub interes RP lub zagrożenie dla zdrowia publicznego. ${ }^{35}$

Obok omówionych powyżej wskaźników Agencja Frontex analizując problem nielegalnej migracji podaje również wskaźnik liczby wydanych odmów wjazdu na terytorium UE. Jest to wskaźnik, który pozwala na określenie presji nielegalnej migracji do Europy.

Zgodnie z art. 13 kodeksu granicznego Schengen ${ }^{36}$ decyzję o odmowie wjazdu na zewnętrznej granicy państw członkowskich wydaje się cudzoziemcowi, który:

1) nie posiada ważnego dokumentu podróży lub dokumentu uprawniającego do przekroczenia granicy;

2) nie posiada ważnej wizy, jeżeli jest wymagana lub nie posiada ważnego dokumentu pobytowego;

3) nie uzasadnił celu i warunków planowanego pobytu oraz nie posiada wystarczających środków utrzymania, zarówno na czas trwania planowanego pobytu, jak i na powrót do państwa pochodzenia lub na tranzyt do państwa trzeciego;

4) którego dane widnieją w SIS do celów odmowy wjazdu;

5) uważany jest za stanowiącego zagrożenie dla porządku publicznego, bezpieczeństwa wewnętrznego, zdrowia publicznego lub stosunków międzynarodowych jednego z państw członkowskich, a w szczególności jeśli dokonano wobec niego na tej samej podstawie, wpisu do celów odmowy wjazdu w bazach krajowych

Polski ustawodawca w art. 28 ust. 1 Ustawy o cudzoziemcach powtórzył te same przesłanki dodając jeszcze 2 sytuacje, a mianowicie gdy cudzoziemiec posiada ważne dokumenty, ale wykorzystał dopuszczalny okres pobytu na terytorium państw obszaru Schengen wynoszący 90 dni w każdym okresie 180 dni, a także gdy cudzoziemiec posiada podrobiony lub przerobiony dokument podróży, wizę lub inny dokument uprawniający go do wjazdu na terytorium Rzeczypospolitej Polskiej i pobytu na tym terytorium.

\section{DYNAMIKA I STRUKTURA NIELEGALNEJ MIGRACJI W EUROPIE}

Przedstawione powyżej aspekty prawne nielegalnej migracji pozwoliły na udzielenie odpowiedzi czy poszczególne formy zachowania określonego mianem nielegalnej migracji są zachowaniami sprzecznymi z prawem. Z kryminologicznej

${ }^{35}$ P. Dąbrowski, [w:] Ustawa o cudzoziemcach. Komentarz, J. Chlebny (red.), C.H. Beck Warszawa 2015, s. 702-706.

${ }^{36}$ Rozporządzenie (WE) Parlamentu Europejskiego i Rady z 15.03.2006 r. ustanawiające wspólnotowy kodeks zasad regulujących przepływ osób przez granice (Kodeks Graniczny Schengen) - Dz. Urz. UE L105 z 13.04.2006 r. 
perspektywy warto zatem przyjrzeć się temu jak wyglądała struktura i dynamika tych zachowań na przestrzeni ostatnich pięciu lat.

Tabela 2. Ujawnieni cudzoziemcy, którzy nielegalnie przekroczyli granice zewnętrzne UE

\begin{tabular}{|l|r|r|r|r|r|}
\hline \multicolumn{1}{|c|}{ Szlaki } & \multicolumn{1}{c|}{2011} & \multicolumn{1}{c|}{2012} & \multicolumn{1}{c|}{2013} & \multicolumn{1}{c|}{2014} & \multicolumn{1}{c|}{2015} \\
\hline Wschodnio-śródziemnomorski & 57025 & 37224 & 24799 & 50834 & 885386 \\
\hline Zachodnio-bałkański & 4658 & 6391 & 19951 & 43357 & 764038 \\
\hline Środkowo-śródziemnomorski & 64261 & 15151 & 45298 & 170664 & 153946 \\
\hline Zachodnio-śródziemnomorski & 8448 & 6397 & 6838 & 7842 & 7164 \\
\hline $\begin{array}{l}\text { Cyrkulacyjny (z Albanii do } \\
\text { Grecji) }\end{array}$ & 5269 & 5502 & 8728 & 8841 & 8932 \\
\hline Wschodni-lądowy & 1049 & 1597 & 1316 & 1275 & 1920 \\
\hline Zachodnio-afrykański & 340 & 174 & 283 & 276 & 874 \\
\hline Czarnomorski & 0 & 1 & 148 & 433 & 68 \\
\hline Razem & 141051 & 72437 & 107365 & 282962 & 1822337 \\
\hline
\end{tabular}

Źródło: Frontex, Annual Risk Analysis 2016, Warsaw 2016, s. 14.

Zgodnie z danymi przedstawionymi w tabeli 2. Agencja Frontex w latach 2011-2015 zdiagnozowała 8 szlaków nielegalnej migracji wiodących do Europy. Większość z nich prowadziła przez południowe wybrzeża Europy. Rok 2015 był rekordowy pod względem liczby cudzoziemców, którzy przekroczyli granice zewnętrzne UE poza przejściami granicznymi na wszystkich szlakach.

Szlak wschodnio-śródziemnomorski prowadził z Turcji do UE przez Grecję, Bułgarię i Cypr drogą morską i lądową. W roku 2015 ujawniono na nim rekordową jak dotąd liczbę nielegalnych migrantów pochodzących głównie z Syrii, Afganistanu oraz Iraku. Najwięcej osób ujawnionych zostało na granicy morskiej. ${ }^{37}$ Jeszcze w latach 2010-2011 na szlaku tym ujawniano najwięcej obywateli Pakistanu i Afganistanu. ${ }^{38}$ Dopiero od 2012 r. dominowały tam zatrzymania obywateli Syrii.

Szlak zachodnio-bałkański był drogą tranzytową dla migrantów przekraczających granicę grecko-turecką i próbujących przedostać się do innych państw członkowskich przez Macedonię i Serbię. W ostatnich dwóch latach najwięcej zatrzymań miało miejsce na granicy węgiersko-serbskiej. ${ }^{39}$ Jeszcze w 2014 r. najwięcej zatrzymanych na tym szlaku stanowili obywatele Kosowa, Afganistanu oraz Syrii. ${ }^{40}$ Od roku 2015 najwięcej zatrzymanych stanowily osoby o nieustalonym obywatelstwie, oraz obywatele Syrii i Afganistanu. ${ }^{41} \mathrm{Z}$ roku na rok zmieniła się diametralnie sytuacja na tym szlaku. Masową migrację przez granicę węgierską

\footnotetext{
${ }^{37}$ FRAN, Quarterly, Quarter 3, July-September 2015, Frontex, Warsaw 2015, s. 6-8.

${ }^{38}$ Frontex, Annual Risk Analysis 2012, Warsaw 2012, s. 14, 21.

${ }^{39}$ Frontex, Annual Risk Analysis 2015, Warsaw 2015, s. 22, 16.

${ }^{40}$ Ibidem.

${ }^{41}$ FRAN, op. cit.
} 
powstrzymała dopiero budowa płotu na granicy węgiersko-serbskiej, a w zasadzie jego podniesienie w październiku 2015 r. Migranci zatem zaczęli kierować się ku granicy słoweńskiej i przez to państwo oraz przez Austrię kierują się dalej do Europy Zachodniej i Północnej. ${ }^{42}$

Na szklaku środkowo-śródziemnomorskim, prowadzącym z Tunezji i Libii do UE przez Włochy i Maltę, ujawnionych zostało najwięcej obywateli Erytrei, Nigerii Somalii. ${ }^{43}$ oraz spora liczba osób o nieokreślonym obywatelstwie pochodzących z regionu Afryki Subsaharyjskiej. W latach 2012-2014 to na tym odcinku zatrzymywano najwięcej nielegalnych migrantów z Tunezji, Nigerii, Somalii, Erytrei, Syrii Afryki Centralnej..$^{44} \mathrm{~W}$ roku 2015 szlak ten ustąpił miejsca szlakowi wschodnio-śródziemnomorskiemu oraz zachodnio-bałkańskiemu ${ }^{45}$ za sprawą spadku liczby obywateli Syrii, którzy aktualnie częściej wybierają szlak bałkański.

Szlak zachodnio-śródziemnomorski prowadzi z państw wschodniej Afryki do UE przez Hiszpanię (głównie Wyspy Kanaryjskie). Aktualnie tą drogą do Europy usiłują przedostać się obywateli Gwinei, Algierii oraz Maroka. ${ }^{46} \mathrm{~W}$ latach 2009-2012 na tym szlaku najczęściej ujawniano obywateli Tunezji, Nigerii, Somalii oraz Erytrei. ${ }^{47}$

Cyrkulacyjnym szlakiem prowadzącym z Albanii do UE przez Grecję docierali stale przede wszystkim obywatele Albanii. Sporadycznie pojawiali się obywatele innych państw np. Macedonii, Gruzji oraz Kosowa. Nielegalna migracja obywateli Albanii do UE malała od końca roku 2010 od kiedy UE zniosła obowiązki wizowe wobec tej grupy cudzoziemców. ${ }^{48} \mathrm{~W}$ latach 2013-2015 liczba ujawnionych osób nielegalnie przekraczających granice na tym szlaku utrzymywała się na stałym poziomie. ${ }^{49}$

Lądowy szlak określony mianem wschodniego-lądowego lub granic wschodnich prowadził do UE przez Estonię, Finlandię, Łotwę, Litwę, Polskę, Słowację, Węgry i Rumunię. W ostatnich latach szlakiem tym usiłują przedostać się obywatele Afganistanu, Wietnamu, Gruzji, Syrii. ${ }^{50} \mathrm{~W}$ roku 2015 cudzoziemcy zaczęli wykorzystywać nowy tzw. szlak arktyczny prowadzący z Rosji do Norwegii i Finlandii. ${ }^{51}$

Nielegalna migracja szlakiem zachodnio-afrykańskim, prowadzącym z Senegalu, Mauretanii i Maroka do UE przez Hiszpanię (głównie Wyspy Kanaryjskie)

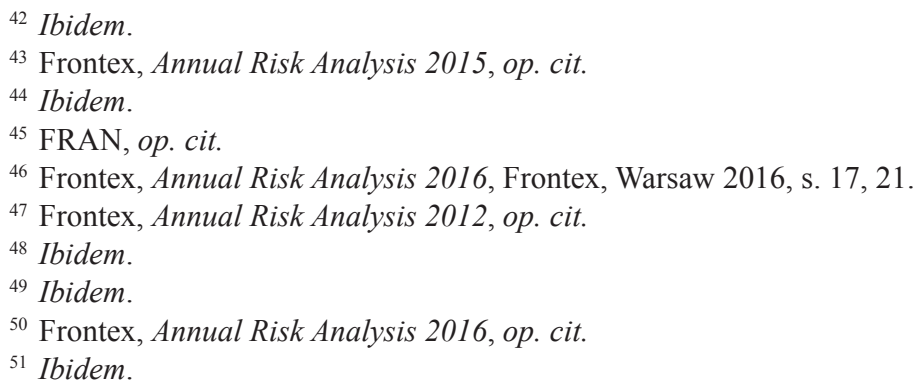


to głównie migracja ludności Gwinei, Wybrzeża Kości Słoniowej, Gambii ${ }^{52}$ oraz Maroka $^{53}$. Szlakiem czarnomorskim, biegnącym z Turcji, Rosji i Ukrainy do UE przez Bułgarię i Rumunię nielicznie dostawali się do UE obywatele Afganistanu. ${ }^{54}$ Syrii, Iraku, Iranu. ${ }^{55}$

Analizując problem migracji do UE drogą morską należy zwrócić uwagę na problem „,zmiany obywatelstwa”. Migranci często pozbywają się dokumentów tożsamości. Po przybyciu do Europy podają się za obywateli państw dotkniętych aktualnie konfliktami czy klęskami żywiołowymi aby zwiększyć swoją szansę na uzyskanie ochrony międzynarodowej. Ich identyfikacja jest trudna, a czasami wręcz niemożliwa.

W tym miejscu należy zastanowić się nad zasadnością ubiegania się o udzielenie ochrony międzynarodowej. Status uchodźcy może zostać udzielony jedynie osobie, która spełnia przesłanki określone w art. 31 Konwencji Genewskiej, co musi zostać stwierdzone przez odpowiednie instytucje państwa przyjmującego. De facto niewielu imigrantów przybywających do UE spełnia te warunki, a przede wszystkim jest w stanie je wykazać. Mogą oni skorzystać z indywidualnej decyzji państwa, jaką jest prawo do azylu, czy z innych form ochrony międzynarodowej przewidzianej przez krajowe porządki prawne. W przypadku jednak udzielenia decyzji odmownej w zakresie udzielenia ochrony zobowiązani zostają do dobrowolnego lub przymusowego opuszczenia terytorium państwa UE. Należy także pamiętać, iż np. w przypadku Polski większość (ok. 80\%) złożonych wniosków o nadanie statusu uchodźcy jest umarzana zwykle ze względu na brak zainteresowania ze strony aplikanta kontynuacją sprawy. ${ }^{56}$

Obok nielegalnego przekroczenia granicy w mniejszej skali występuje proceder posługiwania się fałszywym dokumentem. Stanowi to drugie co do wielkości odnotowywane nielegalne zachowanie. Częściej cudzoziemcy posługują się przerobionym dokumentem niż podrobionym. Najwięcej takich zachowań wykrywanych jest na lotniczych przejściach granicznych, tam gdzie bez dokumentu przekroczenie granicy nie jest możliwe. W przeciwieństwie do granicy lądowej dającej możliwość przekroczenia tzw. zielonej granicy, czy też granicy morskiej. Na europejskich przejściach lotniczych i morskich aktualnie najwięcej cudzoziemców posługujących się fałszywymi dokumentami to obywatele Syrii, ale także Ukrainy. Ci ostatni usiłują przekroczyć granicę polsko-ukraińską oraz polsko-niemiecką posługując się przerobionymi dokumentami podróży lub wyłudzonymi na podstawie fałszach oświadczeń wizami. Obywatele Syrii, Maroka, Albanii Iranu, Iraku oraz Konga najczęściej posługują się przerobionymi dokumentami niemieckimi, a Nigerii dokumentami brytyjskimi.

\footnotetext{
${ }^{52}$ Ibidem.

${ }^{53}$ Frontex, Annual Risk Analysis 2013, Warsaw 2013, s. 21.

${ }^{54}$ Frontex, Annual Risk Analysis 2015, op. cit.

${ }^{55}$ Frontex, Annual Risk Analysis 2016, op. cit.

${ }^{56}$ Komentarz do danych dotyczących 2014 roku Urzędu ds. Cudzoziemców http://udsc.gov. pl/statystyki/raporty-okresowe/zestawienia-roczne/ dostęp 22.03.2016.
} 
Jak już wspomniano istotnym elementem przeciwdziałania nielegalnej migracji jest instytucja odmowy wjazdu na terytorium UE udzielana cudzoziemcom na zewnętrznych granicach UE. Największa liczba odmów wjazdu udzielana jest na granicach lądowych oraz lotniczych. Najwięcej odmów wjazdu wydawanych jest przez Polskę. Przykładowo można podać, iż na granicach RP nie zezwolono na wjazd w 2014 r. 27687 cudzoziemcom (w 2013 r. - 42 451). Należy tu jednak podkreślić, iż udzielenie odmowy wjazdu możliwe jest w przypadku lądowych, lotniczych oraz morskich przejść granicznych. Takiej odmowy z przyczyn humanitarnych nie można wydać cudzoziemcom przybywającym drogą morską na niesprawnych łodziach czy statkach. Stąd też struktura obywatelstwa cudzoziemców, którym udzielono takiej odmowy to głównie obywatele Ukrainy, Albanii, Rosji, Serbii czy Białorusi. Najczęstszą przyczyną wydania odmowy wjazdu jest brak uzasadnienia celu podróży, a także brak wizy, brak środków na utrzymanie oraz zakaz wjazdu nałożony na cudzoziemca.

Tabela 3. Cudzoziemcy, którym udzielono odmowy wjazdu na terytorium UE wg obywatelstwa

\begin{tabular}{|c|c|c|c|c|c|}
\hline Granica & 2011 & 2012 & 2013 & 2014 & 2015 \\
\hline Ladowa & 59592 & 65105 & 78606 & 63701 & 66503 \\
\hline Lotnicza & 49419 & 44063 & 44785 & 46292 & 46713 \\
\hline Morska & 9266 & 7356 & 5844 & 4894 & 5279 \\
\hline Razem & 118277 & 116524 & 129235 & 114887 & 118495 \\
\hline \multicolumn{6}{|l|}{ Obywatelstwo } \\
\hline Ukraina & 15811 & 18108 & 16380 & 16809 & 25283 \\
\hline Albania & 15983 & 12060 & 11564 & 12999 & 15025 \\
\hline Rosja & 9225 & 10113 & 22698 & 10776 & 10671 \\
\hline Serbia & 6672 & 5652 & 8181 & 8657 & 6883 \\
\hline Białoruś & 5983 & 5035 & 4572 & 5172 & 4715 \\
\hline Gruzja & 2801 & 8846 & 8100 & 5100 & b.d. \\
\hline Maroko & 4168 & 4256 & 5372 & 4439 & 4085 \\
\hline Bośnia i Hercegowina & 1762 & 1693 & 3523 & 4010 & 3784 \\
\hline Turcja & 3353 & 3086 & 2999 & 3048 & 3250 \\
\hline Algieria & 1270 & 1407 & 2075 & 2730 & 2435. \\
\hline Pozostałe & 51249 & 46268 & 43771 & 41147 & 42364 \\
\hline
\end{tabular}

Źródło: Frontex, Annual Risk Analysis 2016, Warsaw 2016, s. 66.

Oszacowanie ilu cudzoziemców przebywa w UE nielegalnie jest niezwykle trudne. Każdego roku różne instytucje państw członkowskich ujawniają cudzoziemców, którzy nie mają prawa pobytu. Ciemną liczbę stanowią przypadki tych osób, których nielegalny pobyt nie został ujawniony i zazwyczaj funkcjonują one w szarej strefie do czasu ich ujawnienia przez odpowiednie służby, co czasami może trwać latami. W roku 2015 najwięcej cudzoziemców nielegalnie przebywających w UE stanowili obywatele Syrii, Afganistanu, Iraku oraz Erytrei. Jeszcze w 2013 r. większość ujawnionych nielegalnie przebywających stanowili obywatele Maroka. Niepokojącym zjawiskiem jest rosnąca liczba osób o nieokreślonym 
obywatelstwie. Ujawnieni cudzoziemcy przebywający w UE nielegalnie często nie posiadają przy sobie dokumentów pozwalających na ujawnienie ich tożsamości, a przede wszystkim kraju pochodzenia. Jest to zabieg celowy gdyż znacznie utrudnia a nawet uniemożliwia ich wydalenia z UE, ze względu na brak możliwości ustalenia państwa odpowiedzialnego za przyjęcie takiego cudzoziemca.

Tabela 4. Nielegalny pobyt w UE

\begin{tabular}{|l|r|r|r|r|r|}
\hline Obywatelstwo & \multicolumn{1}{|c|}{2011} & \multicolumn{1}{|c|}{2012} & \multicolumn{1}{c|}{2013} & \multicolumn{1}{c|}{2014} & \multicolumn{1}{c|}{2015} \\
\hline Syria & 3746 & 11967 & 26374 & 74723 & 140261 \\
\hline Erytrea & 6803 & 5024 & 8486 & 34477 & 39330 \\
\hline Maroko & 21887 & 21268 & 26254 & 25329 & 32549 \\
\hline Afganistan & 25296 & 24395 & 16851 & 23393 & 95755 \\
\hline Albania & 10207 & 13264 & 16175 & 20283 & 28485 \\
\hline Ukraina & 12847 & 13081 & 12472 & 16744 & 22615 \\
\hline Algieria & 15398 & 15776 & 14474 & 12993 & 15587 \\
\hline Pakistan & 12621 & 18334 & 14209 & 11650 & 23199 \\
\hline Kosowo & 2728 & 3949 & 6349 & 10900 & 16018 \\
\hline Nieokreślone & 6814 & 9126 & 20598 & 24461 & b.d. \\
\hline Pozostałe & 232601 & 208744 & 182856 & 186827 & 287816 \\
\hline Razem & 350948 & 344928 & 345098 & 441780 & 701625 \\
\hline
\end{tabular}

Źródło: Frontex, Annual Risk Analysis 2016, Warsaw, 65.

Od 2012 r. rocznie w UE wydawanych było ponad 200 tys. decyzji o zobowiązaniu cudzoziemca do powrotu (w roku 2015 r. było to 286725 decyzji). Przy czym wykonywanych było około 150 tys. decyzji rocznie (w 2015 r. wykonano 175220 decyzji).

\section{WNIOSKI}

Nielegalna migracja jest zjawiskiem złożonych i niejednolitym. Przeprowadzona analiza prawna $\mathrm{w}$ zakresie nielegalnej migracji pozwoliła na ukazanie różnych aspektów sytuacji prawnej cudzoziemca przekraczającego granicę czy przebywającego na terytorium państwa członkowskiego. Zachowania cudzoziemców składające się na proceder nielegalnej migracji przybierając różne formy. Od najczęściej występującego przekroczenia granicy państwa wbrew przepisom, przez przestępstwa przeciwko wiarygodności dokumentów a kończąc na wykorzystywaniu procedury udzielenia ochrony międzynarodowej np. poprzez bezpodstawne ubieganie się o nadanie statutu uchodźcy. Skala zachowań składających się na zjawisko nielegalnej migracji w Europie stale rośnie. Zarówno rośnie liczba osób przekraczających nielegalnie granicę zewnętrzną UE, jak również liczba osób, które przebywają nielegalnie na terytorium UE. 
Unia Europejska a także poszczególne państwa członkowskie starają się reagować na problem. Niemniej jednak jego rozwiązanie nie jest proste i w największej mierze zależy od sytuacji w państwach wysyłających. Nie tylko tej politycznej, społecznej czy ekonomicznej. Nie bez znaczenia jest także aktywność zorganizowanych grup przestępczych, organizujących proceder czerpiących z tego korzyści.

Title: Illegal Migration in Europe - Legal and Criminological Aspects

\begin{abstract}
It the time of actual discussion on illegal migration in Europe it is important to analyze which behaviors constitutes the phenomenon. Therefore the first part of the article indicates the behaviors that are called the illegal migration. They are: illegal border crossing, use of fraudulent documents or illegal stay. Author made the legal analysis trying to state if those acts are forbidden by law, especially referring to Polish criminal and administrative law. The second part presents the dynamics and structure of phenomenon in the period of last five years. The structure presents the nationalities of immigrants and the routes leading to Europe.
\end{abstract}

Keywords: migration, illegal border crossing, refugees 